\title{
Post- marsupial development of Hyalella pleoacuta (Crustacea: Amphipoda): stages 1-4
}

\author{
Deise Leda Garcia-Schroeder \& Paula Beatriz Araujo
}

\begin{abstract}
Departamento de Zoologia, PPG Biologia Animal. Instituto de Biociências, Universidade Federal do Rio Grande do Sul. Avenida Bento Gonçalves, 9500, Prédio 43435, 91501-970 Porto Alegre, RS, Brasil.

E-mail: deisegarcia@hotmail.com; pbaraujo@portoweb.com.br
\end{abstract}

\begin{abstract}
The goal of this study is to describe and compare the initial stages of the post-marsupial development of Hyalella pleoacuta González, Bond-Buckup \& Araujo, 2006, prior to the development of sexual dimorphism. Ovigerous females were collected in São José dos Ausentes, RS, Brazil and kept in laboratory. Juveniles were kept separately after emerging from the marsupium and were monitored daily for the presence of exuvia. Individuals from post-marsupial stages (S) 1 to 4 were dissected and illustrated. Cuticular structures were observed through SEM. Twenty three types of setae, one type of setule, two types of pores, two types of denticles and one type of penicilium were found. Cuticular structures undergo modification through development in the matters of haste size, number and size of setules, and formation of the polygonal pattern, although there is no change from one type to another. Gnathopods and antennae are the appendages that go through more modifications. The articles number of the flagellum is constant until S2. The size of the coxal plate of gnathopods in relation to the propodus has a tendency to increase throughout the stages. The uropod proportion becomes smaller in S3 when compared to S1. The number of serrate setae in the external plate of maxilla 1 varies up to 54 , being different from the adult whose number is 9 . The telson modifies its shape but its setae number is constant.
\end{abstract}

KEY WORDS. Cuticular structures; juveniles; morphology.

In aquatic environments, amphipods of the genus Hyalella Smith, 1874 are generally found associated with macrophytes, in the water column, or buried in the sediment (WeLLBORN 1995). They constitute an important component of the diet of fish, birds, and invertebrates (Muskó 1993, Pilgrim \& BURT 1993). They are abundant in these environments (AIKINs \& KIKUCHI 2001) and because of their sensitivity to environmental disturbances they are used as bioindicators and biomonitors for assessing water quality, bioaccumulation, effects on feeding activity, growth and sediment toxicity (NEUPARTH et al. 2002, RiNDERHAGEN et al. 2000).

In amphipods, fertilization and development of the eggs occur in the marsupium, where the juveniles remain for some time after they hatch (BELLAN-SANTINI 1999). The marsupium is formed by the ventral surface of the segments and by the oostegites, which are plates formed on the inner surface of the thoracic coxae, generally of segments 2 to 5 (KAÏм-MALKA 2004). In juvenile females, they appear as small projections, and develop progressively until the parturial molt (BELLAN-SANTIN 1999). Males bear penial papillae that are located on the sternum of the last thoracic segment, through which the spermatozoids are released. Development is direct, and on leaving the marsupium the young show most of the adult characteristics except for sexual dimorphism (BELLAN-SANTINI 1999). UNGERER \& WolfF (2005), describing the embryonic development of Orchestia cavimana Heller, 1865, observed that the seventh thoracic appendage begins its development in the same way as the others, thus showing that there is no manca stage, not even in the embryo.

Because the appendages of amphipods change profoundly during their development (Leite \& Wakabara 1989, Leite \& Leite 1997), the description of the initial developmental stages is of great importance because it helps in studies of growth and population dynamics (Morino 1978, Page 1979, Leite \& WaKabara 1989) as well as in taxonomy (SEXton \& ReId 1951, Rygg 1974, Sтоск 1987). The morphology of the developmental stages of Amphilocus neapolitanus Della Valle, 1893, Ampithoe ramondi Audouin, 1826 (Leite 1996), Hyale media Dana, 1830 (Leite \& WAKABARA 1989), and Sunampithoe pelagica Milne-Edwards, 1830 (Leite \& GÜth 2003) has been described, based on the gnathopods, antennas, and cephalothorax length. In all these species, there is a tendency for the antennal flagellum to add one article in each stage, although there is variation among individuals; and for the size and number of setae on the gnathopods to increase in each stage, principally in gnathopod 2 of the male after sexual differentiation. 
Of the 12 species of Hyalella recorded from Brazil (GonZALEZ et al. 2006), only the biology of $H$. castroi González, Bond-Buckup \& Araujo, 2006 and H. pleoacuta González, Bond-Buckup \& Araujo, 2006 has been investigated. CASTIGLIONI \& Bond-Buckup (2007) studied the postembryonic development of $H$. pleoacuta, and observed that following birth the juveniles remain in the marsupium from 1 to 6 days and do not molt during this period. For the same species, Castiglioni et al. (2007) recorded that after the young leave the marsupium, the first, second, third and fourth molts occur, on average, respectively after (days \pm E.P.) $7.1 \pm 0.13$ (stage $1, S-1), 6.0 \pm 0.13$ (S-2), $6.0 \pm 0.11$ (S-3) and $6.6 \pm 0.17$ (S-4). They observed that sexual dimorphism appears in several structures: oostegites, penial papilla and differences in the gnathopods in stage 5 , but sexual maturity is reached after stage 8 in both sexes. Examination of the cuticular structure of adults of $H$. pleoacuta showed that there is no sexual differentiation in the distribution and type of setae, except on the propodus of gnathopod 2 (ZIMMER et al. 2009).

The objective of the present study was to describe and compare the initial stages, prior to the appearance of sexual dimorphism, of the post-marsupial development in $H$. pleoacuta. This involved describing the morphology of the appendages in general aspect, as well as in the types, development, and distribution of the cuticular structures.

\section{MATERIAL AND METHODS}

Ovigerous females of $H$. pleoacuta were collected in culture ponds for trout Onchorhynchus mykiss (Walbaum, 1792) in the Vale das Trutas, municipality of São José dos Ausentes, Rio Grande do Sul $\left(28^{\circ} 47^{\prime} 00^{\prime \prime} \mathrm{S} 49^{\circ} 50^{\prime} 53^{\prime \prime} \mathrm{W}\right)$, and transported to the Carcinology Laboratory (Universidade Federal do Rio Grande do Sul). They were maintained under controlled conditions of temperature $\left(19^{\circ} \mathrm{C} \pm 1\right)$, light intensity ( \pm 1000 lux $)$ and photoperiod (12/12 h), and fed on leaves of Callitriche rimosa Fasset, 1951 and three drops of the alga Ankistrodesmus sp. Corda, 1838 ( $3.5 \times 10^{6}$ cells $\left./ \mathrm{ml}\right)$ every two days.

After they left the marsupium, the juveniles were separated and maintained under the same conditions. These procedures were used by CASTIGLIONI et al. (2007) to culture the same species. The containers were checked daily for the presence of exuviae.

For scanning electron microscopy (SEM), the juveniles were dissected and prepared using techniques adapted from Leistikow \& Araujo (2001): dehydration for 30 minutes in each ethanol solution at concentrations of 70, 75, 80, 85, 90, 95, and $100 \%$, ethanol-acetone (1:1), and pure acetone, critical point drying, and coating with carbon and gold. The material was photographed in a Jeol JSM-6060 scanning electron microscope.

For the observation of the setae, appendages from five specimens of each stage were used. The terminology for the setae followed the classification of ZiMMER et al. (2009), which describes the types of cuticular structures found in two species of Hyalella. The terminology uses symbols composed of a letter that signifies the category, followed by a number that designates the type of cuticular structure. For example, the structures with letter " $A$ " refer to a seta of the "simple seta" category: A1 refers to the lamellate simple seta, whereas A2 refers to the A2 simple seta. The morphology of the appendages of the juveniles was compared with that of the adults as described by Gonzalez et al. (2006) and Zimmer et al. (2009).

The stages were determined from the molts: stage 1 (S$1)$, juveniles released from the marsupium, until the first molt; stage 2 (S-2), juveniles between the first and second molts; stage 3 (S-3), juveniles between the second and third molts; and stage 4 (S-4), juveniles between the third and fourth molts (see CAstiglioni et al. 2007). Juveniles of all four stages were dissected under a stereoscopic microscope, and the appendages were mounted on slides in glycerin. The appendages were illustrated with the aid of a drawing tube mounted on an optical microscope. The gnathopods and antennas were drawn for S-1 through S-4. The remaining appendages were drawn only for S-1 and S-3, because of the small degree of variation in their morphology in relation to the next stages.

\section{RESULTS}

\section{Cuticular structures}

The following cuticular structures were found on the appendages of the first four stages of post-marsupial development of H. pleoacuta: 1) Simple setae: A1 (Fig. 1), A2 (Fig. 2), A3 (Fig. 3), A4 (Fig. 4), A5 (Fig. 4), A7, A8 (Fig. 6), A10 (Fig. 8). 2) Cuspidate setae: B1 (Fig. 9), B2 (Figs 10 and 11), B3 (Fig. 11), B5 (Fig. 12), B6 (Fig. 13). 3) Plumose setae: C1, C2 (Fig. 14). 4) Pappose setae: D3 (Fig. 9), D4 (Fig. 15), D5 (Fig. 16), D6 (Fig. 17). 5) Serrulate setae: E1 (Fig. 18). 6) Serrate setae: F1 e F2 (Fig. 2), F3 (Figs 19-21), F4 (Fig. 22). 7) Setules: S2 (Figs 24-26). 8) Denticles: T1 (Figs 27 and 28), T2 (Fig. 29). 9) Pores: P1 e P2 (Fig. 26). 10) Penicillium: (Figs 31 and 32).

The number and type of setae on each appendage of the juvenile stages are in table I.

\section{Appendages}

Antenna 1. Peduncle triarticulate, flagellum with 3-6 articles in the different stages (Tab. II).

S-1 (Fig. 33): articles of the peduncle little differentiated from the flagellum in shape and size. Article 1 approximately as wide as long, and with a row of small C2 plumose setae (Fig.14). Articles 2 and 3 with A1 simple setae (Fig.1). Flagellum with three articles, with A1 simple setae (Fig.1) and A8 aesthetascs (Fig.6) on the 1st and 2nd articles. S-2 (Fig. 34): articles of peduncle not differentiated from the flagellar articles, but with the first article slightly longer than wide, and all articles of the peduncle wider than those of the flagellum. Same types of setae as in S-1, with the addition of B6 cuspidate setae (Fig.13) on article 1 of the peduncle. Flagellum with four articles, with aesthetascs (A8 seta, Fig. 7) on articles 2 and 3. S-3 (Fig. 35): articles of peduncle little differentiated from the flagellum. Same 


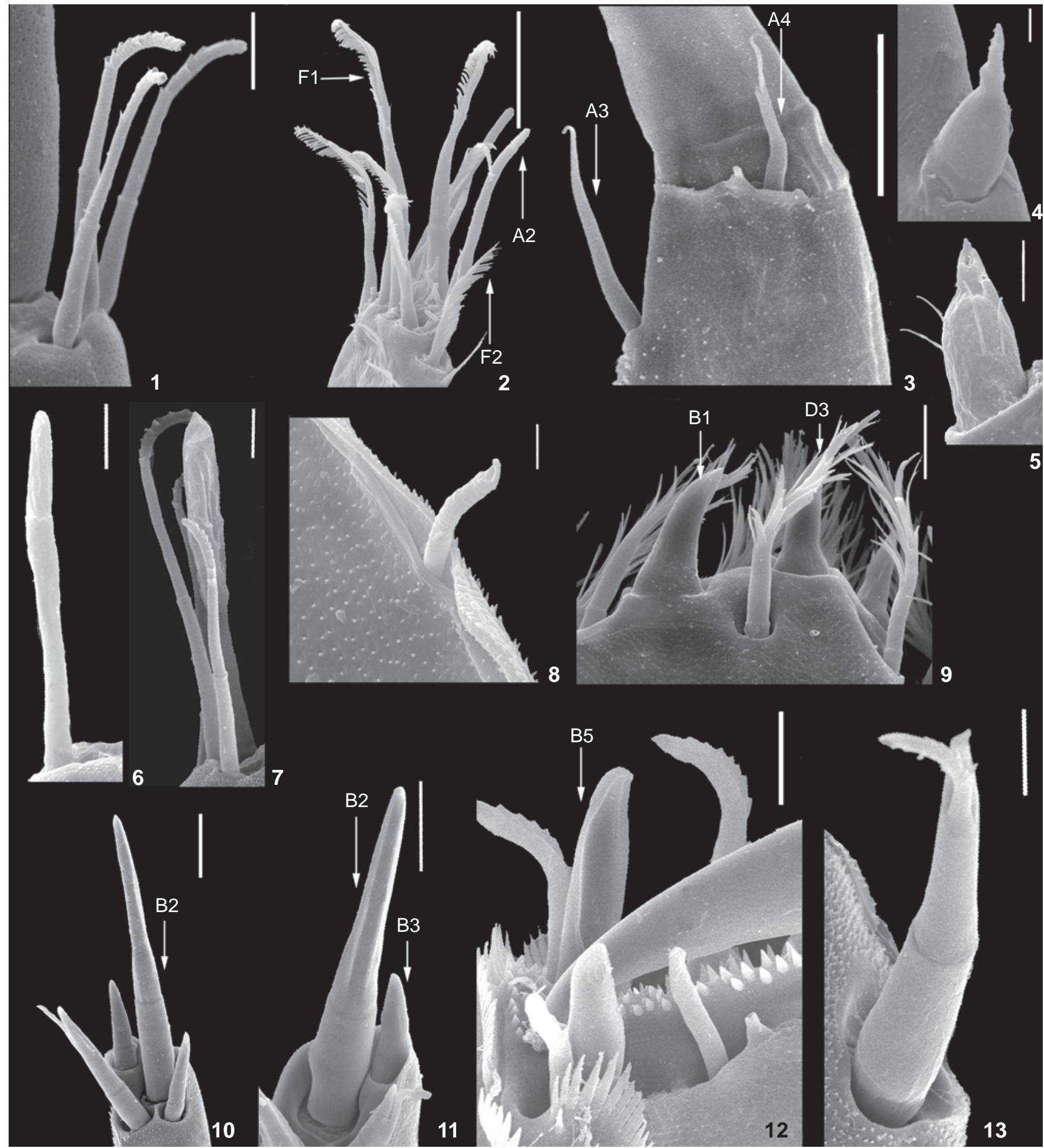

Figures 1-13. Hyalella pleoacuta: (1) A1 seta of flagellum of antenna 1, S-1; (2) A2 setae, F1 and F2 of the outer maxilla plate 2, S-1; (3) A3 and A4 setae of dactylus of pereopod, S-3; (4) A5 seta, palp of maxilla 1, S-1; (5) A5 seta of palp of maxilla 1, S-4; (6) A8 seta of flagellum of antenna 1, S-1; (7) A8 seta, flagellum of antenna 1, S-4; (8) A10 seta, coxa of gnathopod, S-4; (9) B1 and D3 setae, inner plate of maxilliped, S-3; (10) B2 seta of uropod, 1 S-1; (11) B2 and B3 setae of inner ramus of uropod 1, S-4; (12) B5 seta of propodus of gnathopod, S-4; (13) B6 seta of telson, S-4. Scale: 1, 5, 6, 7, 9, 12 and $13=5 \mu \mathrm{m} ; 2,3,10$ and $11=10 \mu \mathrm{m} ; 4$ and $8=2 \mu \mathrm{m}$. 
Table I. Number and type of setae on each appendage of the juveniles in the first four stages of post-marsupial development of $H$. pleoacuta. The symbols between parentheses refer to the type of cuticular structure, according to the classification of ZIMMER et al. (2009): simple setae (A1-A5, A8 and A10), cuspidate (B1-B3, B5 and B6), plumose (C1 and C2), pappose (D3-D6), serrulate (E1), serrate (F1-F4), setule (S2), denticles (T1 and T2), pores (P1 and P2) and penicillium.

\begin{tabular}{|c|c|c|c|c|}
\hline Appendage & Stage 1 & Stage 2 & Stage 3 & Stage 4 \\
\hline \multicolumn{5}{|l|}{ Antenna 1} \\
\hline \multicolumn{5}{|l|}{ Peduncle } \\
\hline Article 1 & $0-5(\mathrm{C} 2)$ & 4-7 (B6 e C2) & 4-7 (B6 e C2) & 3-6 (A1, B6 e C2) \\
\hline Article 2 & $2-3(\mathrm{~A} 1)$ & 2-6 (A1) & 3-7 (A1) & $5-6(\mathrm{~A} 1)$ \\
\hline Article 3 & $0-3(\mathrm{~A} 1)$ & 3-6 (A1) & 4-6 (A1) & $3-6(\mathrm{~A} 1)$ \\
\hline Flagellum & $9-15(\mathrm{~A} 1, \mathrm{~A} 7 \mathrm{e} \mathrm{A} 8)$ & $12-16(\mathrm{~A} 1, \mathrm{~A} 7$ e $\mathrm{A} 8)$ & $16-20(\mathrm{~A} 1, \mathrm{~A} 7 \mathrm{e} \mathrm{A} 8)$ & $17-23(\mathrm{~A} 1, \mathrm{~A} 7 \mathrm{e}$ A8) \\
\hline \multicolumn{5}{|l|}{ Antenna 2} \\
\hline \multicolumn{5}{|l|}{ Peduncle } \\
\hline Article 1 & 0 & 0 & 0 & 0 \\
\hline Article 2 & 0 & 0 & 0 & $1(\mathrm{~A} 1)$ \\
\hline Article 3 & $3(\mathrm{~A} 1, \mathrm{~F} 3)$ & $2-4(\mathrm{~A} 1, \mathrm{~F} 3)$ & $3-4(\mathrm{~A} 1, \mathrm{~F} 3)$ & $1-5(\mathrm{~A} 1, \mathrm{~F} 3)$ \\
\hline Article 4 & $3-4(\mathrm{~A} 1, \mathrm{~F} 3, \mathrm{C} 2)$ & 3-7 (A1, F3, C2) & 4-7 (A1, F3, C2) & 4-7 (A1, F3 e C2) \\
\hline Article 5 & $3-5(\mathrm{~A} 1, \mathrm{C} 2)$ & $4-5(\mathrm{~A} 1, \mathrm{C} 2)$ & $5-6(\mathrm{~A} 1, \mathrm{C} 2)$ & $3-6(A 1, C 2)$ \\
\hline Flagellum & $11-15(\mathrm{~A} 1)$ & $13-19(\mathrm{~A} 1)$ & $22-29(\mathrm{~A} 1)$ & $23-36(\mathrm{~A} 1)$ \\
\hline Upper labium & S1, P1 e P2 & $\mathrm{S} 1, \mathrm{P} 1$ e $\mathrm{P} 2$ & $\mathrm{~S} 1, \mathrm{P} 1$ e $\mathrm{P} 2$ & $S 1, P 1$ e $P 2$ \\
\hline Right mandible & 3-4 penicillium + S1 & 4 penicillium + S1 & 4 penicillium + S1 & 4 penicillium + S1 \\
\hline Left mandible & 3 penicillium + S1 & 3 penicillium + S1 & 3 penicillium + S1 & 3 penicillium + S1 \\
\hline Lower labium & S2 e $\mathrm{P} 2$ & S2 e $\mathrm{P} 2$ & S2 e $\mathrm{P} 2$ & S2 e P2 \\
\hline \multicolumn{5}{|l|}{ Maxilla 1} \\
\hline Palp & 1 (A5) & $1(\mathrm{~A} 5)+\mathrm{S} 2$ & $1(\mathrm{~A} 5)+\mathrm{S} 2$ & $1(\mathrm{~A} 5)+\mathrm{S} 2$ \\
\hline Inner plate & $2(D 6)+S 2$ & $2(D 6)+S 2$ & $2(\mathrm{D} 6)+\mathrm{S} 2$ & $2(D 6)+S 2$ \\
\hline Outer plate & $4-7(F 4)+S 2$ & $8(F 4)+S 2$ & $8-9(F 4)+S 2$ & $8-9(F 4)+S 2$ \\
\hline \multicolumn{5}{|l|}{ Maxilla 2} \\
\hline Inner plate & $7-9(\mathrm{~A} 2, \mathrm{D} 5$ e $\mathrm{E} 1)+\mathrm{S} 2$ & 7-9 (A2, D5, E1 e F1) +S2 & $7-10(\mathrm{~A} 2, \mathrm{D} 5, \mathrm{E} 1$ e $\mathrm{F} 1)+\mathrm{S} 2$ & $9-10(\mathrm{~A} 2, \mathrm{D} 5, \mathrm{E} 1$ e $\mathrm{F} 1)+\mathrm{S} 2$ \\
\hline Outer plate & $7-9(\mathrm{~A} 2, \mathrm{~F} 1$ e $\mathrm{F} 2)+\mathrm{S} 2$ & $6-9(A 2, F 1$ e F2) + S2 & $7-8(\mathrm{~A} 2, \mathrm{~F} 1$ e $\mathrm{F} 2)+\mathrm{S} 2$ & $9-12(\mathrm{~A} 2, \mathrm{~F} 1$ e F2) + S2 \\
\hline \multicolumn{5}{|l|}{ Maxilliped } \\
\hline Inner plate & 6-7 (B1, D3 e D4) + S2 & 8-11 (B1, D3 e D4) + S2 & $7-12(B 1, D 3$ e D4) + S2 & $7-12(B 1, D 3$ e D4) + S2 \\
\hline Outer plate & $4-8(\mathrm{~A} 1, \mathrm{~A} 2$ e $\mathrm{D} 3)+\mathrm{P} 2$ & $7-9(\mathrm{~A} 1, \mathrm{~A} 2$ e $\mathrm{D} 3)+\mathrm{P} 2$ & $7-9(\mathrm{~A} 1, \mathrm{~A} 2$ e $\mathrm{D} 3)+\mathrm{P} 2$ & $8-13(\mathrm{~A} 1, \mathrm{~A} 2$ e $\mathrm{D} 3)+\mathrm{P} 2$ \\
\hline \multicolumn{5}{|l|}{ Palp } \\
\hline Article 1 & $1(\mathrm{~A} 1)$ & 0-1 (A1) & $1(\mathrm{~A} 1)$ & 0-1 (A1) \\
\hline Article 2 & $2(\mathrm{~A} 1)$ & $2-5(\mathrm{~A} 1$ e $\mathrm{A} 2)$ & 4-6 (A1 e A2) & $6-10(\mathrm{~A} 1$ e $\mathrm{A} 2)$ \\
\hline Article 3 & $5-7(\mathrm{~A} 1, \mathrm{~A} 2$ e $\mathrm{F} 3)+\mathrm{S} 2$ eT1 & 6-7 (A1, A2 e F3) + S2 eT1 & $6-9(\mathrm{~A} 1, \mathrm{~A} 2$ e F3) + S2 eT1 & $6-11(\mathrm{~A} 1, \mathrm{~A} 2$ e $\mathrm{F} 3)+\mathrm{S} 2 \mathrm{eT} 1$ \\
\hline Article 4 & $3-4(\mathrm{~A} 1, \mathrm{~A} 2$ e $\mathrm{F} 3)+\mathrm{S} 2 \mathrm{eT} 1$ & $4-5(\mathrm{~A} 1, \mathrm{~A} 2 \mathrm{e} F 3)+\mathrm{S} 2 \mathrm{eT} 1$ & $3-4(\mathrm{~A} 1, \mathrm{~A} 2$ e $\mathrm{F} 3)+\mathrm{S} 2$ eT1 & $3-4(\mathrm{~A} 1, \mathrm{~A} 2$ e $\mathrm{F} 3)+\mathrm{S} 2 \mathrm{eT} 1$ \\
\hline \multicolumn{5}{|l|}{ Gnathopod 1} \\
\hline Coxa & $0-2(\mathrm{~A} 10)$ & $3(\mathrm{~A} 10)$ & $2-4(\mathrm{~A} 10)$ & $4(\mathrm{~A} 10)$ \\
\hline Basis & $1(\mathrm{~F} 3)+\mathrm{T} 1$ & $0-1(F 3)+T 1$ & $1(\mathrm{~F} 3$ e $\mathrm{T} 1)$ & 1 (F3 e T1) \\
\hline Ischium & $1(F 3)+T 1$ & 0-1 (F3 e T1) & $0-1(\mathrm{~F} 3$ e T1) & $0-1(\mathrm{~F} 3$ e T1) \\
\hline Merus & $1(\mathrm{~F} 3)+\mathrm{T} 1$ & $0-1(\mathrm{~F} 3$ e $\mathrm{T} 1)$ & $1(\mathrm{~F} 3$ e $\mathrm{T} 1)$ & 1 (F3 e T1) \\
\hline Carpus & $1-2(F 3)+T$ & $2-4(F 3)+T$ & $4-5(F 3)+T$ & $4-5(F 3)+T$ \\
\hline Propodus & $2(\mathrm{~B} 4$ e $\mathrm{A} 1)+\mathrm{T}$ & $5-7(B 4, F 3$ e $A 1)+T$ & $6-9(B 4, F 3$ e $A 1)+T$ & $7-10(B 4, F 3$ e $A 1)+T$ \\
\hline Dactylus & $3(C 2, A 1$ e $A 7)+T$ & $1-3(C 2, A 1$ e $A 7)+T$ & $2-4(C 2, A 1$ e $A 7)+T$ & $3-6(C 2, A 1$ e $A 7)+T$ \\
\hline
\end{tabular}


Table I. Continued.

\begin{tabular}{|c|c|c|c|c|}
\hline Appendage & Stage 1 & Stage 2 & Stage 3 & Stage 4 \\
\hline \multicolumn{5}{|l|}{ Gnathopod 2} \\
\hline Coxa & $0-1(\mathrm{~A} 10)$ & $2-3(\mathrm{~A} 10)$ & $3-4(\mathrm{~A} 10)$ & $4(\mathrm{~A} 10)$ \\
\hline Basis & $1(\mathrm{~F} 3)+\mathrm{T} 1$ & $0-1(F 3)+T 1$ & 1 (F3 e T1) & $0-1$ (F3 e T1) \\
\hline Ischium & $1(\mathrm{~F} 3)+\mathrm{T} 1$ & $0-1(F 3)+T 1$ & 1 (F3 e T1) & 1 (F3 e T1) \\
\hline Merus & $1(\mathrm{~F} 3)+\mathrm{T} 1$ & $0-1(F 3)+T 1$ & 1 (F3 e T1) & $1-3(\mathrm{~F} 3$ e $\mathrm{T} 1)$ \\
\hline Carpus & $1-2(F 3)+T$ & $2-3(F 3)+T$ & $3-5(F 3)+T$ & $3-5(F 3)+T$ \\
\hline Propodus & $3-4(B 4$ e $A 1)+T$ & $5-6(B 4, F 3$ e $A 1)+T$ & $5-9(B 4, F 3$ e $A 1)+T$ & $6-9(B 4, F 3$ e $A 1)+T$ \\
\hline Dactylus & $1-2(\mathrm{C} 2$ e $\mathrm{A} 1)+\mathrm{T}$ & $1-3(C 2, A 1$ e $A 7)+T$ & $1-4(C 2, A 1$ e $A 7)+T$ & $1-6(C 2, A 1$ e $A 7)+T$ \\
\hline \multicolumn{5}{|l|}{ Pereopods 3} \\
\hline Coxa & $1-2(\mathrm{~A} 10)$ & $2-3(A 10)$ & $3(\mathrm{~A} 10)$ & $2-5(\mathrm{~A} 10)$ \\
\hline Basis & $1-2(\mathrm{~A} 1$ e $\mathrm{F} 3)$ & $1-2(\mathrm{~A} 1$ e $\mathrm{F} 3)$ & $1-2(\mathrm{~A} 1$ e $\mathrm{F} 3)$ & $0-2(\mathrm{~A} 1$ e $\mathrm{F} 3)$ \\
\hline Ischium & $1(\mathrm{~A} 1)$ & $0-1(\mathrm{~A} 1)$ & 1 (A1) & $1(\mathrm{~A} 1)$ \\
\hline Merus & $1(\mathrm{~A} 1)$ & $2-3(\mathrm{~A} 1$ e $\mathrm{B} 6)$ & $2-3(\mathrm{~A} 1$ e $\mathrm{B} 6)$ & $3-4(\mathrm{~A} 1$ e $\mathrm{B} 6)$ \\
\hline Carpus & $1-2(\mathrm{~A} 1$ e $\mathrm{B} 6)$ & $3-4(\mathrm{~A} 1$ e $\mathrm{B} 6)$ & $1-3(\mathrm{~A} 1$ e $\mathrm{B} 6)$ & $3-4(\mathrm{~A} 1$ e $\mathrm{B} 6)$ \\
\hline Propodus & $3-4(\mathrm{~A} 1$ e $\mathrm{B} 6)$ & $3-4(\mathrm{~A} 1$ e $\mathrm{B} 6)$ & $3-5(\mathrm{~A} 1$ e $\mathrm{B} 6)$ & $3-6(A 1$ e $B 6)$ \\
\hline Dactylus & $0-1(\mathrm{~A} 4)$ & $2(\mathrm{~A} 3$ e $\mathrm{A} 4)$ & $2(\mathrm{~A} 3$ e $\mathrm{A} 4)$ & $1-2(\mathrm{~A} 3$ e $\mathrm{A} 4)$ \\
\hline \multicolumn{5}{|l|}{ Pereopods 4} \\
\hline Coxa & $2(\mathrm{~A} 10)$ & $2-3(A 10)$ & $3-4(A 10)$ & 4-6 (A10) \\
\hline Basis & $1-2(\mathrm{~A} 1$ e $F 3)$ & $0-2(\mathrm{~A} 1$ e $\mathrm{F} 3)$ & $1-2(\mathrm{~A} 1$ e $\mathrm{F} 3)$ & $0-2(\mathrm{~A} 1$ e $\mathrm{F} 3)$ \\
\hline Ischium & $1(\mathrm{~A} 1)$ & 0-1 (A1) & $0-1(\mathrm{~A} 1)$ & $0-1(\mathrm{~A} 1)$ \\
\hline Merus & $1(\mathrm{~A} 1)$ & $0-2(\mathrm{~A} 1$ e $\mathrm{B} 6)$ & $2-3(\mathrm{~A} 1$ e $\mathrm{B} 6)$ & $3-4(\mathrm{~A} 1$ e $\mathrm{B} 6)$ \\
\hline Carpus & $2(\mathrm{~A} 1$ e $\mathrm{B} 6)$ & $2-3(\mathrm{~A} 1$ e $\mathrm{B} 6)$ & $3-4(\mathrm{~A} 1$ e $\mathrm{B} 6)$ & $3-5(\mathrm{~A} 1$ e $\mathrm{B} 6)$ \\
\hline Propodus & $3-4(A 1$ e $B 6)$ & $3-4(\mathrm{~A} 1$ e $\mathrm{B} 6)$ & $3-5$ (A1 e $B 6)$ & 5-6 (A1 e B6) \\
\hline Dactylus & $1-2(\mathrm{~A} 3$ e $\mathrm{A} 4)$ & $1-2(\mathrm{~A} 3$ e $\mathrm{A} 4)$ & $1-2(\mathrm{~A} 3$ e $\mathrm{A} 4)$ & $2(\mathrm{~A} 3$ e $\mathrm{A} 4)$ \\
\hline \multicolumn{5}{|l|}{ Pereopods 5} \\
\hline Coxa & 1 (A10) & $1-2(A 10)$ & $2-3(\mathrm{~A} 10)$ & $1-2(\mathrm{~A} 10)$ \\
\hline Basis & $0-2(\mathrm{~A} 1$ e $\mathrm{F} 3)$ & $2-3(\mathrm{~A} 1$ e $F 3)$ & $2-4(\mathrm{~A} 1$ e $F 3)$ & $3-5$ (A1 e F3) \\
\hline Ischium & $1(\mathrm{~A} 1)$ & 1 (A1) & $1(\mathrm{~A} 1)$ & $1(\mathrm{~A} 1)$ \\
\hline Merus & $2-3(\mathrm{~A} 1)$ & $2-3(\mathrm{~A} 1$ e $\mathrm{B} 6)$ & $3-4(\mathrm{~A} 1$ e $\mathrm{B} 6)$ & $3-6(\mathrm{~A} 1$ e $\mathrm{B} 6)$ \\
\hline Carpus & $2-3(\mathrm{~A} 1$ e $\mathrm{B} 6)$ & 4 (A1 e $B 6)$ & $3-4(\mathrm{~A} 1$ e $\mathrm{B} 6)$ & $4-5$ (A1 e $B 6)$ \\
\hline Propodus & $2-3(\mathrm{~A} 1$ e $\mathrm{B} 6)$ & $3-4(\mathrm{~A} 1$ e $\mathrm{B} 6)$ & $4-5$ (A1 e $B 6)$ & 4-5 (A1 e $B 6)$ \\
\hline Dactylus & $0-1$ (A4) & $1-2(\mathrm{~A} 3$ e $\mathrm{A} 4)$ & $2(\mathrm{~A} 3$ e $\mathrm{A} 4)$ & $1-3(\mathrm{~A} 3$ e $\mathrm{A} 4)$ \\
\hline \multicolumn{5}{|l|}{ Pereopods 6} \\
\hline Coxa & 1 (A10) & 1 (A10) & 1 (A10) & $0-1(\mathrm{~A} 10)$ \\
\hline Basis & 2 (A1 e F3) & 2 (A1 e F3) & $2-4(\mathrm{~A} 1$ e $F 3)$ & $2-4(\mathrm{~A} 1$ e $\mathrm{F} 3)$ \\
\hline Ischium & $1(\mathrm{~A} 1)$ & 1 (A1) & $1(\mathrm{~A} 1)$ & $1(\mathrm{~A} 1)$ \\
\hline Merus & 2 (A1 e B6) & 3 (A1 e B6) & $3-4(\mathrm{~A} 1$ e $\mathrm{B} 6)$ & 5-6 (A1 e B6) \\
\hline Carpus & 3 (A1 e B6) & $4-5(\mathrm{~A} 1$ e $\mathrm{B} 6)$ & 4-7 (A1 e B6) & $6-8(\mathrm{~A} 1$ e $\mathrm{B} 6)$ \\
\hline Propodus & 4-5 (A1 e B6) & $5-8(\mathrm{~A} 1$ e $\mathrm{B} 6)$ & $5-9(\mathrm{~A} 1$ e $\mathrm{B} 6)$ & $6-10(\mathrm{~A} 1$ e $\mathrm{B} 6)$ \\
\hline Dactylus & $1-2(\mathrm{~A} 3$ e $\mathrm{A} 4)$ & $1-2(\mathrm{~A} 3$ e $\mathrm{A} 4)$ & $2-3(\mathrm{~A} 3$ e $\mathrm{A} 4)$ & $2(\mathrm{~A} 3$ e $\mathrm{A} 4)$ \\
\hline
\end{tabular}


Table I. Continued.

\begin{tabular}{|c|c|c|c|c|}
\hline Appendage & Stage 1 & Stage 2 & Stage 3 & Stage 4 \\
\hline \multicolumn{5}{|l|}{ Pereopods 7} \\
\hline Coxa & 0 & 0-1 (A10) & 1 (A10) & $1(\mathrm{~A} 10)$ \\
\hline Basis & $2(\mathrm{~A} 1$ e F3) & 2 (A1 e F3) & $2-3(\mathrm{~A} 1$ e $\mathrm{F} 3)$ & $2-4(\mathrm{~A} 1$ e $\mathrm{F} 3)$ \\
\hline Ischium & $1(\mathrm{~A} 1)$ & $1(\mathrm{~A} 1)$ & $1(\mathrm{~A} 1)$ & $1-2(\mathrm{~A} 1)$ \\
\hline Merus & $2(\mathrm{~A} 1$ e $\mathrm{B} 6)$ & $3(\mathrm{~A} 1$ e $\mathrm{B} 6)$ & $4(\mathrm{~A} 1$ e $\mathrm{B} 6)$ & $4-5(\mathrm{~A} 1$ e $\mathrm{B} 6)$ \\
\hline Carpus & $2(\mathrm{~A} 1$ e $\mathrm{B} 6)$ & 4-6 (A1 e B6) & 4-7 (A1 e B6) & 5-7 (A1 e $B 6)$ \\
\hline Propodus & $4-5(\mathrm{~A} 1$ e $\mathrm{B} 6)$ & 5-7 (A1 e $B 6)$ & $6-8(\mathrm{~A} 1$ e $\mathrm{B} 6)$ & $5-10(\mathrm{~A} 1$ e $\mathrm{B} 6)$ \\
\hline Dactylus & $1-2(\mathrm{~A} 3$ e $\mathrm{A} 4)$ & $2(\mathrm{~A} 3$ e $\mathrm{A} 4)$ & $2-3(\mathrm{~A} 3$ e $\mathrm{A} 4)$ & $1-3(\mathrm{~A} 3$ e $A 4)$ \\
\hline \multicolumn{5}{|l|}{ Uropod 1} \\
\hline Peduncle & 1 (B6) & $1-3(B 6)$ & $2(\mathrm{~B} 6)$ & $2-3(B 6)$ \\
\hline Inner ramus & $3-4(B 2, B 3$ e $B 6)$ & $4(\mathrm{~B} 2, \mathrm{~B} 3$ e $\mathrm{B} 6)$ & 4 (B2, B3 e B6) & $4-5$ (B2, B3 e B6) \\
\hline Outer ramus & $4-5(B 2, B 3$ e B6) & $3-5(B 2, B 3$ e $B 6)$ & $4-5$ (B2, B3 e B6) & $4-5$ (B2, B3 e B6) \\
\hline \multicolumn{5}{|l|}{ Uropod 2} \\
\hline Peduncle & $0-1(B 6)$ & $1-2(B 6)$ & $1-2(B 6)$ & $0-2(B 6)$ \\
\hline Inner ramus & 3 (B2, B3 e B6) & $4(\mathrm{~B} 2, \mathrm{~B} 3$ e $\mathrm{B} 6)$ & 4 (B2, B3 e B6) & $3-4(B 2, B 3$ e $B 6)$ \\
\hline Outer ramus & $3-4(B 2, B 3$ e $B 6)$ & $4(\mathrm{~B} 2, \mathrm{~B} 3$ e $\mathrm{B} 6)$ & $3-4(B 2, B 3$ e B6) & $3-5$ (B2, B3 e B6) \\
\hline \multicolumn{5}{|l|}{ Uropod 3} \\
\hline Peduncle & $0-1(B 6)$ & $0-1(B 6)$ & $1(\mathrm{~B} 6)$ & 1 (B6) \\
\hline Outer ramus & $1-2(\mathrm{~A} 1$ e $\mathrm{B} 3)$ & 2 (A1 e B3) & 2 (A1 e B3) & $2-3(\mathrm{~A} 1$ e $\mathrm{B} 3)$ \\
\hline Telson & $2(\mathrm{~B} 6)+6(\mathrm{C} 2)$ & $2(\mathrm{~B} 6)+6(\mathrm{C} 2)$ & $2(\mathrm{~B} 6)+6(\mathrm{C} 2)$ & $2(\mathrm{~B} 6)+6(\mathrm{C} 2)$ \\
\hline
\end{tabular}

Table II. Number of articles of the flagellum of antennas 1 and 2 in the first four developmental stages of $H$. pleoacuta. The numbers between parentheses refer to the number of individuals observed. (LA) Left antenna, (RA) right antenna. When not provided, LA = RA.

\begin{tabular}{cccll}
\hline Stages & 1 & \multicolumn{1}{c}{2} & \multicolumn{1}{c}{4} \\
\hline Antenna 1 & $3(20)$ & $4(20)$ & $4(16)$ & $4(1)$ \\
& & & $5(1)$ & $5(15)$ \\
& & & & \\
& & & AE4 AD5 (1) & AE4 AD5 (1) \\
Antenna 2 & $3(20)$ & $4(20)$ & $4(7)$ & $5(6)$ \\
& & & $5(10)$ & $6(9)$ \\
& & & $6(1)$ & $7(1)$ \\
& & & AE6 AD7 (1) & AE5 AD6 (2) \\
& & & AE7 AD6 (1) & \\
\hline
\end{tabular}

types of setae and aesthetascs in the same locations as in S-2, however, the flagellum has 4-6 articles. S-4 (Fig. 36): same types of setae as in S-2, but with the addition of A1 simple setae (Fig. 1) on article 1 . Flagellum varies from two to five articles, with the aesthetascs (Fig.7) restricted to articles 3 and 4 .
Antenna 2. Peduncle with five articles. Article 1 with rounded plate. Article 2 with antenna 1 gland, and wider than high. Article 3 small, but its width approximately equal to that of articles 4 and 5 . Flagellum varies from 3 to 7 articles in the different stages of development (Tab. II). S-1 (Fig. 37): there is no evident separation between the peduncular and flagellar articles. Article 4 wider than article 5, and article 5 wider than the first article of the flagellum. Article 1 of the flagellum, however, is longer than articles 4 and 5 of the peduncle. Articles 1 and 2 without setae. Article 3 with A1 simple (Fig.1) and F3 serrate setae (Fig.20). Article 4 with A1 simple (Fig.1), F3 serrate (Fig.20) and C2 plumose setae (Fig.14). Article 5 with A1 simple (Fig.1) and C2 plumose setae (Fig.14). Flagellum triarticulate, with A1 simple setae (Fig.1). S-2 (Fig. 38): beginning of differentiation between the last articles of the peduncle and the first articles of the flagellum. Articles 4 and 5 larger than the first article of the flagellum. Setae lacking on articles 1 and 2 of the peduncle, as in the preceding stage. Other articles bearing the same types of setae as the S-1. Flagellum with four articles. S-3 (Fig. 39): similar to $\mathrm{S}-2$ in the proportions of the peduncle in relation to the first article of the flagellum. Also similar in regard to the types of setae. The number of articles of the flagellum varies from 4 to 7. S-4 (Fig. 40): peduncular articles robust, differentiated from 


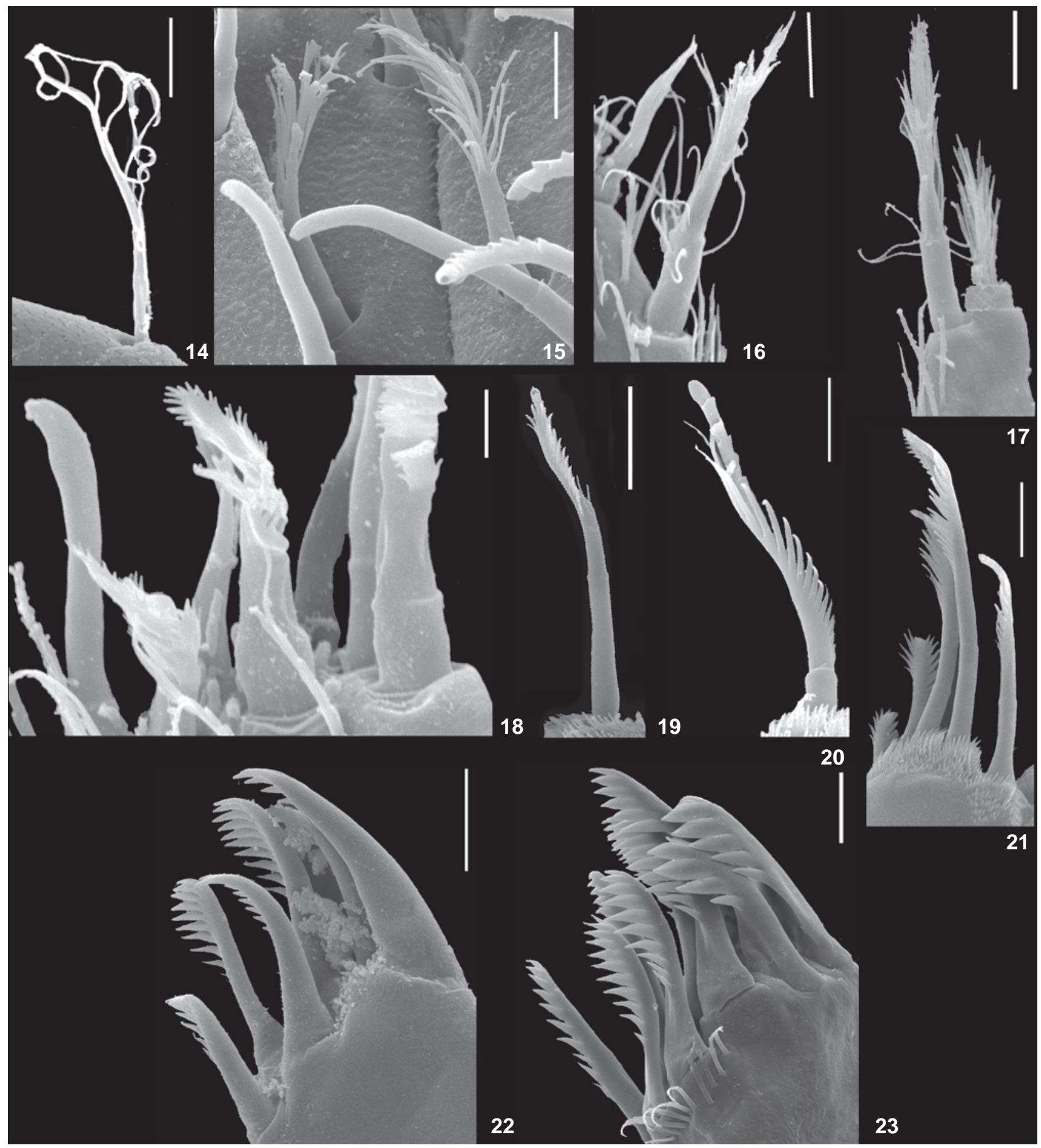

Figures 14-23. Hyalella pleoacuta: (14) C2 seta, dactylus of pereopod 7, S-1; (15) D4 seta, inner plate of maxilliped, S-4; (16) D5 seta, inner plate of maxilla 2, S-1; (17) D6 seta, inner plate of maxilla 1, S-1; (18) E1 seta, inner plate of maxilla 2, S-1; (19) F3 seta, ischium of gnathopod 1, S-2; (20) F3 seta, carpus of gnathopod, S-1; (21) F3 seta, carpus of gnathopod, S-4; (22) F4 seta, outer plate of maxilla 1, S-1; (23) F4 seta, outer plate of maxilla 1, S-3. Scale: 14, 15, 16, 17 and $20=5 \mu \mathrm{m} ; 18=2 \mu \mathrm{m} ; 19,21,22$ and $23=10 \mu \mathrm{m}$. 


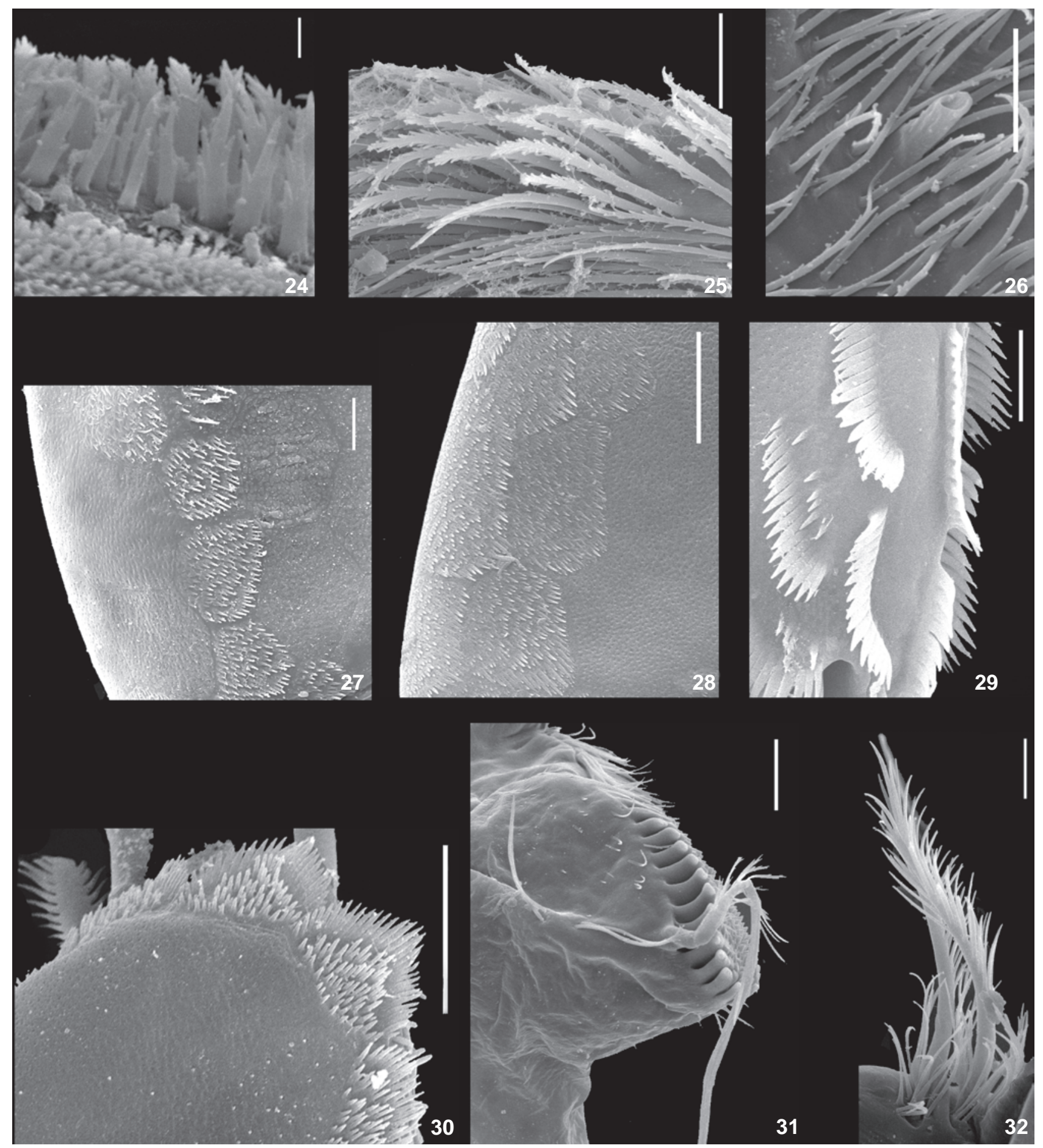

Figures 24-32. Hyalella pleoacuta: (24) S2 setule, upper labium, S-1; (25) S2 setule, upper labium, S-4; (26) P2 pore and setules, lower labium, S-3; (27) T1 denticles, basis of gnathopod, S-1; (28) T1 denticles, basis of gnathopod, S-4; (29) T2 denticles, propodus of gnathopod, S-4; (30) pectinate border of carpus of gnathopod 1, S-4; (31) penicillium near molar process, left mandible, S-3; (32) penicillium beneath lacinia mobilis, right mandible, S-3. Scale: $24=1 \mu \mathrm{m} ; 25,26,27,29$ and $32=5 \mu \mathrm{m} ; 28,30$ and $31=10 \mu \mathrm{m}$. 


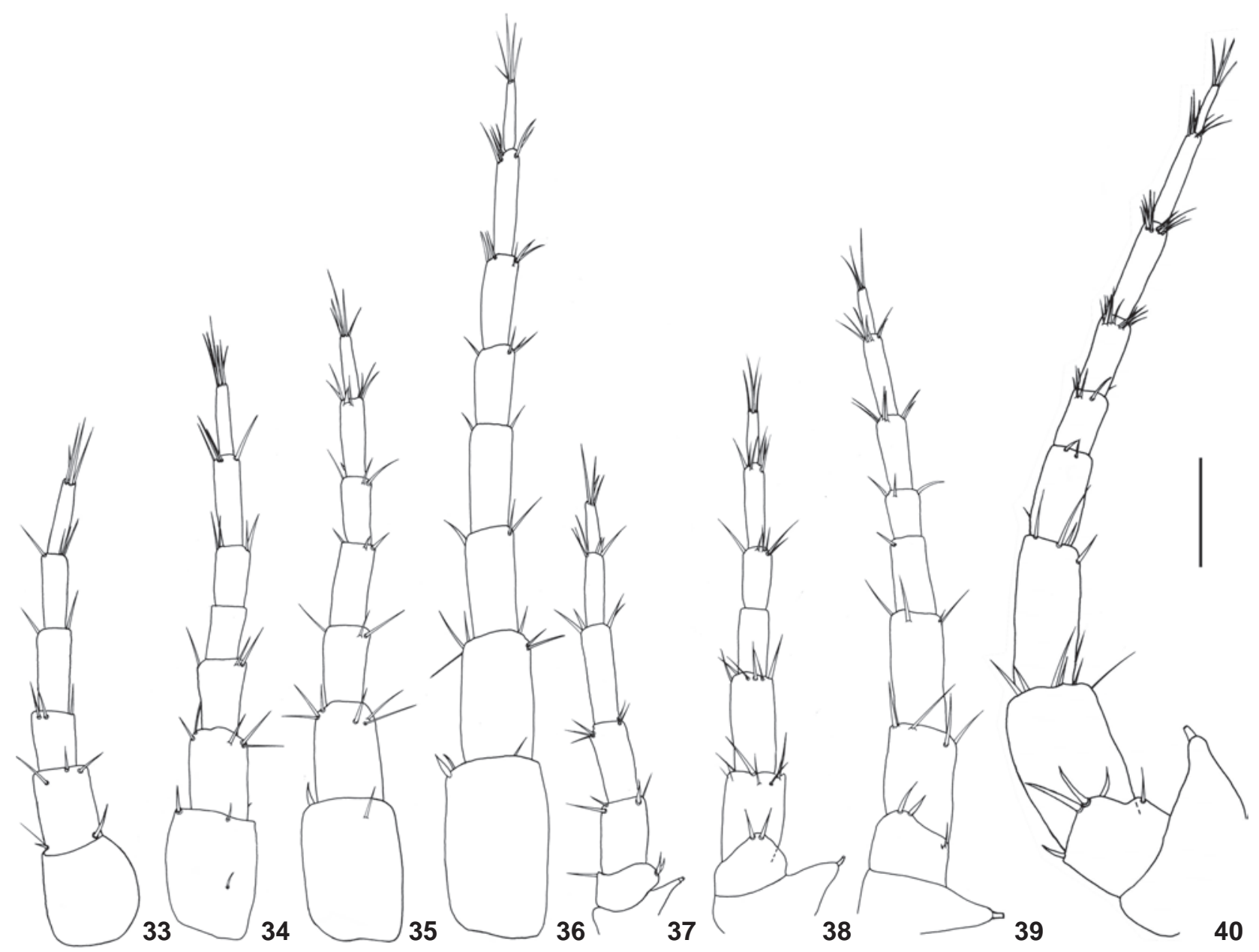

Figures 33-40. Hyalella pleoacuta, antennas 1 and 2 in the first four stages of post-marsupial development: (33-36) antenna 1 of stages 1, 2, 3 and 4, respectively; (37-40) antenna 2 of stages 1, 2, 3 and 4, respectively. Scale $0.1 \mathrm{~mm}$.

flagellar articles. Same types of setae as the preceding stage, but with the addition of an A1 simple seta (Fig.1) on article 2. Flagellum with 5-7 articles.

Gnathopod 1. S-1 (Fig. 41): coxal plate approximately twice as long as propodus. Coxa with A10 simple setae (Fig. 8). Basis, ischium and merus with F3 serrate setae (Fig. 20) and small T1 denticles (Fig. 27), beginning the formation of the polygonal pattern. Carpus with the beginning of a pectinate border, but it is not possible to separate the denticles into T1 and T2 (Figs 27 and 29), with F3 serrate setae (Fig. 20). Propodus (Fig. 49) with two A1 simple (Fig. 1) and B5 cuspidate setae (Fig. 12), and T1 (Fig. 27) and T2 (Fig. 29) denticles. Dactylus with denticles, not differentiated into T1 or T2 (Figs 27 and 29), C2 plumose (Fig. 14) and A1 (Fig. 1) and A7 simple setae. S-2 (Fig. 42): proportions of coxal plate in relation to propodus similar to those of $S$ 1. Similar to stage 1 in respect to the types of setae and development of the denticles, except for the propodus (Fig. 50), which in addition to the setae and denticles of the preceding stage, also has 1 F3 serrate seta on the ventral palm (Fig.19). S-3 (Fig. 43): same types of setae as in stage 2 , but it is now possible to differentiate the denticles into T1 (Fig. 28) on the basis, ischium and merus, and T1 (Fig. 28) and T2 (Fig. 29) on the carpus, forming the pectinate border. Propodus (Fig. 51) with 1-2 F3 serrate setae (Fig. 21) on the ventral palm, in addition to the A1 simple (Fig. 1) and B5 cuspidate setae (Fig. 12). The denticles of the dactylus can also now be differentiated into T1 (Fig. 28) and T2 (Fig. 29). S-4 (Fig. 44): proportions of coxal plate in relation to propodus similar to the preceding stage. Same types of setae and denticles as in S-3. Propodus (Fig. 52) with same types of setae as in preceding stage, but with two F3 serrate setae (Fig.21) on the ventral palm.

Gnathopod 2. S-1 (Fig. 45): coxal plate slightly less than twice as long as the propodus. Coxa with A10 simple setae (Fig.1). Basis, ischium and merus with F3 serrate seta (Fig. 20) and small 
T1 denticles (Fig. 27), beginning to form the polygonal pattern. Carpus with F3 serrate seta (Fig. 20), and denticles not differentiated into T1 or T2 (Figs 27 and 29). Propodus (Fig. 53) with B5 cuspidate setae (Fig. 12) and A1 simple setae (Fig. 1) and denticles present, but denticles not differentiated into T1 or T2 (Figs 27 and 29). Dactylus with denticles, C2 plumose (Fig. 14) and A1 simple setae (Fig.1). S-2 (Fig. 46): coxal plate approximately twice as wide as the propodus. Same types of setae as in S-1, with the addition of 1-2 F3 serrate setae (Fig. 19) on the ventral surface of the propodus (Fig. 54) and an A7 simple seta on the dactylus. It is now possible to differentiate the denticles on T1 (Fig. 28) on the basis, ischium and merus, T1 (Fig. 28) and T2 (Fig. 29) on the carpus, and T2 (Fig. 29) on the propodus. S-3 (Fig. 47): coxal plate, length more than twice the width of the propodus (Fig. 55). Same types of setae present as in S-2.

S-4 (Fig. 48): with similar proportions as the S-3 in regard to the coxal plate relative to the propodus, and the same types of setae, but with two F3 serrate setae (Fig. 21) on the ventral palm of the propodus (Fig. 56).

In these stages the gnathopod 2 is not differentiated, and it is not possible to separate the individuals into males or females by means of this criterion.

\section{Mouthparts, pereopods, uropods and telson in stage 1}

Upper labium (Fig. 60): width/height ratio greater than 1. Dorsal surface with T1 denticles (Fig.27) on the distal part, arranged more proximally to the apex than in the later stages. Sparse S2 setules (Fig. 24) with short shafts on the apex of the appendage. P1 and P2 (Fig. 26) pores present.

Right mandible (Fig. 58): lacinia mobilis bifurcate, 2 penicillia (Fig. 32) with sparse setules on the lacinia and some S2 setules (Fig. 24). A long penicillium (Fig. 31) below the molar process.

Left mandible (Fig. 57): lacinia mobilis with four "teeth", 2-3 penicillia (Fig. 32), with sparse setules on the lacinia and several S1 setules. A long penicillium below the molar process.

Lower labium (Fig. 59): width/height ratio greater than 1. Dorsal part of distal margin covered with S2 setae (Fig. 24), and ventral surface with setules, denticles and pores.

Maxilla 1 (Fig. 61): shape similar to that of the adult, but with narrower outer plate. Palp with very short A5 simple seta (Fig. 4) without setules.Inner plate with D6 pappose setae (Fig. 17) with a long shaft and several S2 setules (Fig. 24). Outer plate with 4-7 F4 serrate setae (Fig. 22) and S2 setules (Fig. 24).

Maxilla 2 (Fig. 62): with similar shape to that of the adult, but with narrower inner plate. Inner plate with A2 simple (Fig. 1), D5 pappose (Fig. 16) and E1 serrulate setae (Fig. 18), and several S2 setules (Fig. 24). Outer plate with A2 simple (Fig. 2), F1 serrate and F2 serrate setae (Fig. 2), in addition to S2 setules (Fig. 24).

Maxilliped (Fig. 63): similar to that of the adult, with setae set less densely, and margins less angular. Inner plate with B1 cuspidate (Fig. 9), D3 pappose (Fig. 9) and D4 pappose setae (Fig. 15), and S2 setules (fig. 24) on the ventral part. Outer plate with A1 simplen(Fig. 1), A2 simple (Fig. 2) and D3 pappose setae (Fig. 9), with sparse setules; P2 pores present (Fig. 26). Palp: Articles 1 and 2 with A1 simple setae (Fig. 1). Articles 3 and 4 with A1 simple (Fig. 1), A2 simple (Fig. 2) and F3 serrate setae (Fig. 19), S2 setules (Fig. 24) and T1 denticles (Fig. 29).

Pereopods (Figs 64-68): similar to those of the adult, with less-dense setae. Coxa with A10 simple setae (Fig. 8), except on pereopod 7. Basis with A1 simple (Fig. 1) and F3 serrate setae (Fig. 19). Ischium with A1 simple setae (Fig. 1). Merus with A1 simple (Fig. 1) and B6 cuspidate setae (Fig. 13). Carpus and propodus with A1 simple (Fig. 1) and B6 cuspidate setae (Fig. 13), and dactylus with A3 (Fig. 3) and A4 simple setae (Fig. 3).

Uropod 1 (Fig. 69): its total length approximately half that of the pereopods. Peduncle with B6 cuspidate seta (Fig. 13). Rami with apical B2 (Fig. 10), B3 (Fig. 11) and B6 cuspidate setae (Fig. 13); the B2 seta (Fig. 10) has the base approximately equal in diameter to the middle of the seta, differing from the seta originally described, which has the portion above the annulus differentiated.

Uropod 2 (Fig. 70): its length slightly less than half that of uropod 1. Peduncle sometimes with B6 cuspidate seta (Fig. 13). Rami with apical B2 (Fig. 10), B3 (Fig. 11) and B6 cuspidate setae (Fig. 13). B2 seta (Fig. 10) similar to that of uropod 1.

Uropod 3 (Fig. 71): its length less than 1/3 that of uropod 2. Peduncle with B6 cuspidate seta (Fig. 13). Outer ramus with A1 (Fig. 1) and B3 cuspidate setae (Fig. 11).

Telson (Fig. 72): slightly larger than uropod 3. 2 B6 (Fig. 13) and 1-3 C2 setae (Fig. 14) on each side.

Pereonite 7 and pleonites 1, 2 and 3 with flanges, as in the adult.

\section{Mouthparts, pereopods, uropods and telson in stage 2}

The mouthparts, pereopods, uropods and telson of stages 2 are similar to those of stages 1 , except in the number of setae on each article of these appendages (Tab. I).

\section{Mouthparts, pereopods, uropods and telson in stage 3}

Upper labium (Fig. 76): width/height ratio smaller than in S-1. With the same types of setules and denticles as in S-1, although these are distributed more widely. Shaft of setules larger than in S-1

Right mandible (Fig. 74): similar to that of S-1 in shape, number and kinds of setae. Lacinia mobilis can be bi- or trifurcate, and the penicillia (Figs 31 and 32) on it have more-densely set setules.

Left mandible (Fig. 73): similar to that of S-1 in shape, number and type of setae, however with three penicillia (Fig. 32) below the lacinia mobilis.

Lower labium (Fig. 75): width/height ratio identical to that in S-1. Dorsal part of distal margin with S2 setules (Fig. 25), distributed slightly more widely than in S-1.

Maxilla 1 (Fig. 78): similar in shape to that in the juvenile $\mathrm{S}-1$, but the palp has setules, with a very short A5 simple seta (Fig. 5). Outer plate has 8-9 F4 setae (Fig. 23). 

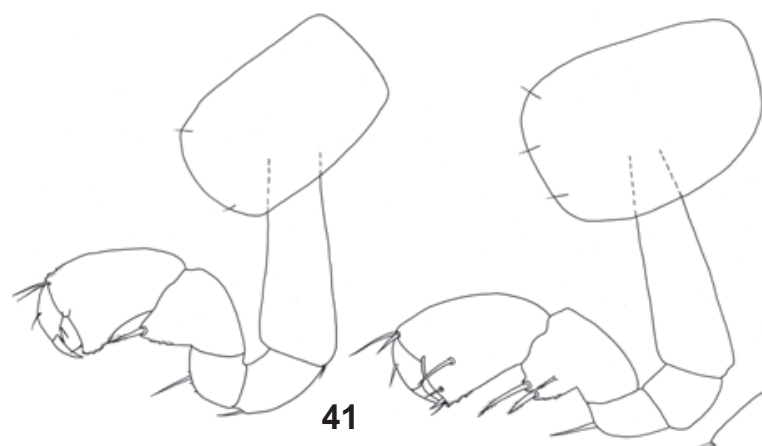

42
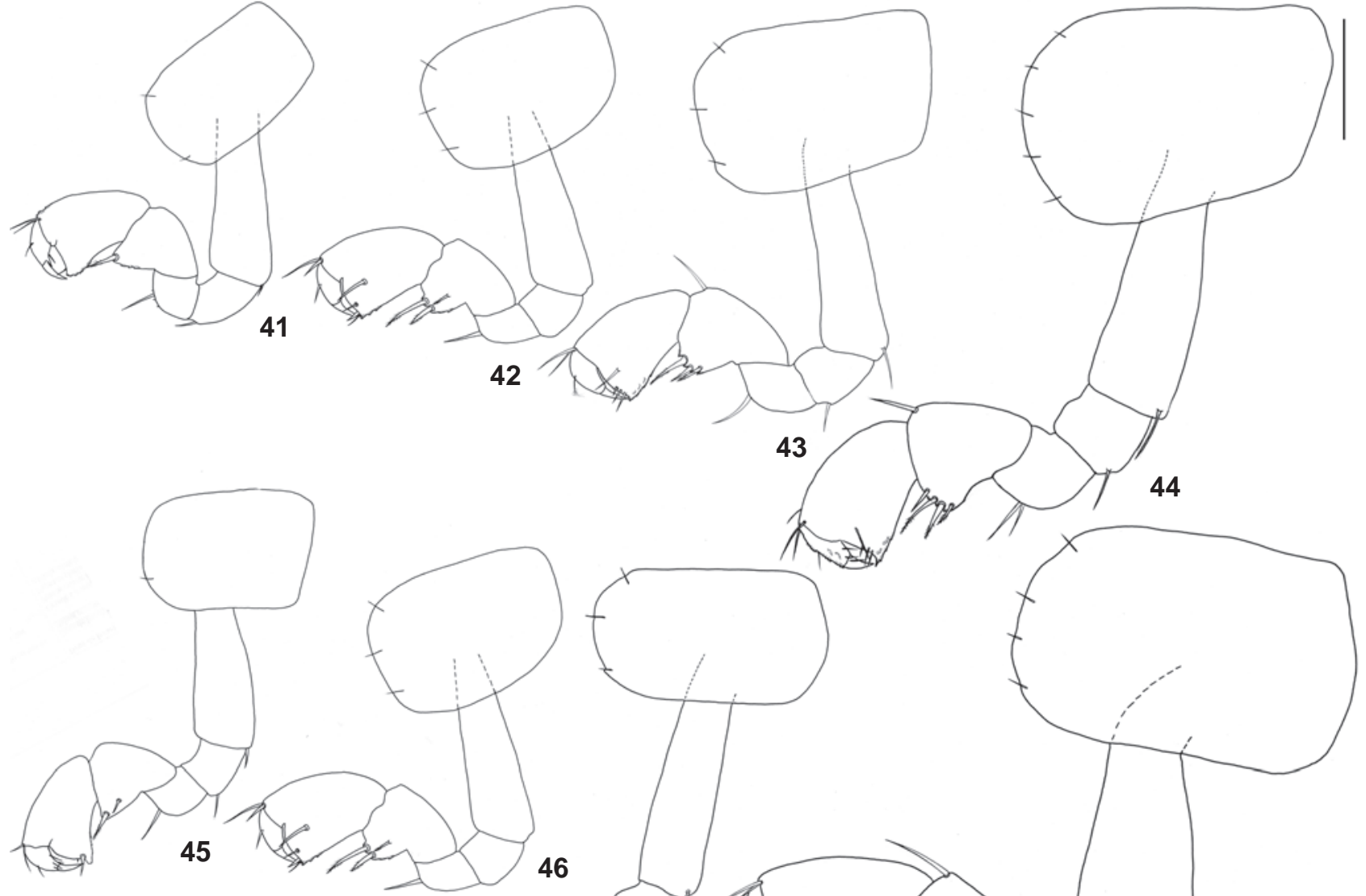

43

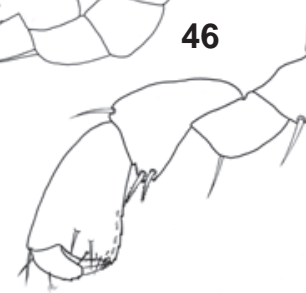

47
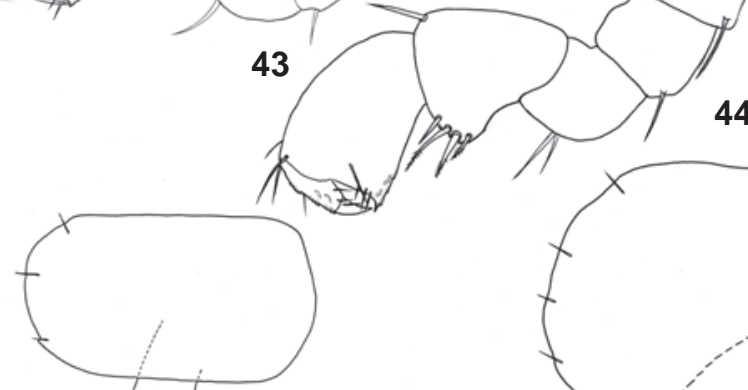

44
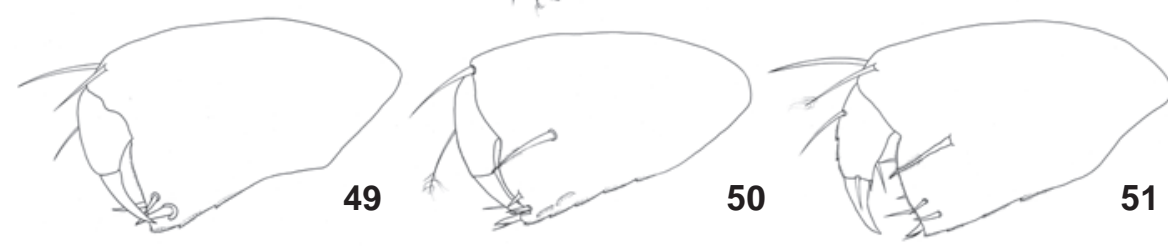

51

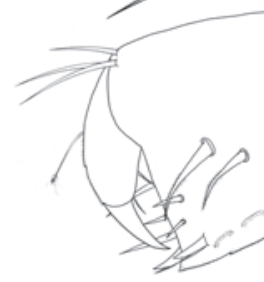

48
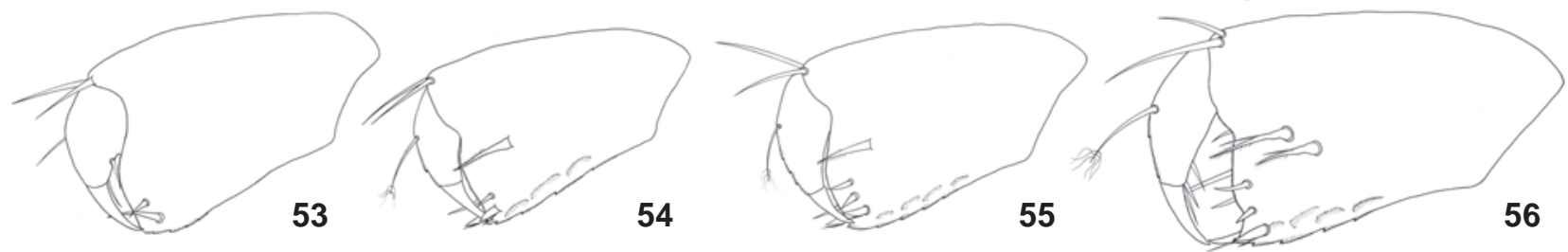

Figures 41-56. Hyalella pleoacuta, gnathopods 1 and 2 in the first four stages of post-marsupial development: (41-44) gnathopods 1 in stages 1, 2, 3 and 4, respectively (scale $0.1 \mathrm{~mm}$ ); (45-48) gnathopods 2 in stages 1, 2, 3 and 4, respectively (scale 0.1 mm); (49-52) propodi of gnathopods 1 in stages 1, 2, 3 and 4, respectively (scale $0.05 \mathrm{~mm}$ ); (53-56) propodi of gnathopods 2 in stages 1, 2, 3 and 4 , respectively (scale $0.05 \mathrm{~mm}$ ). 


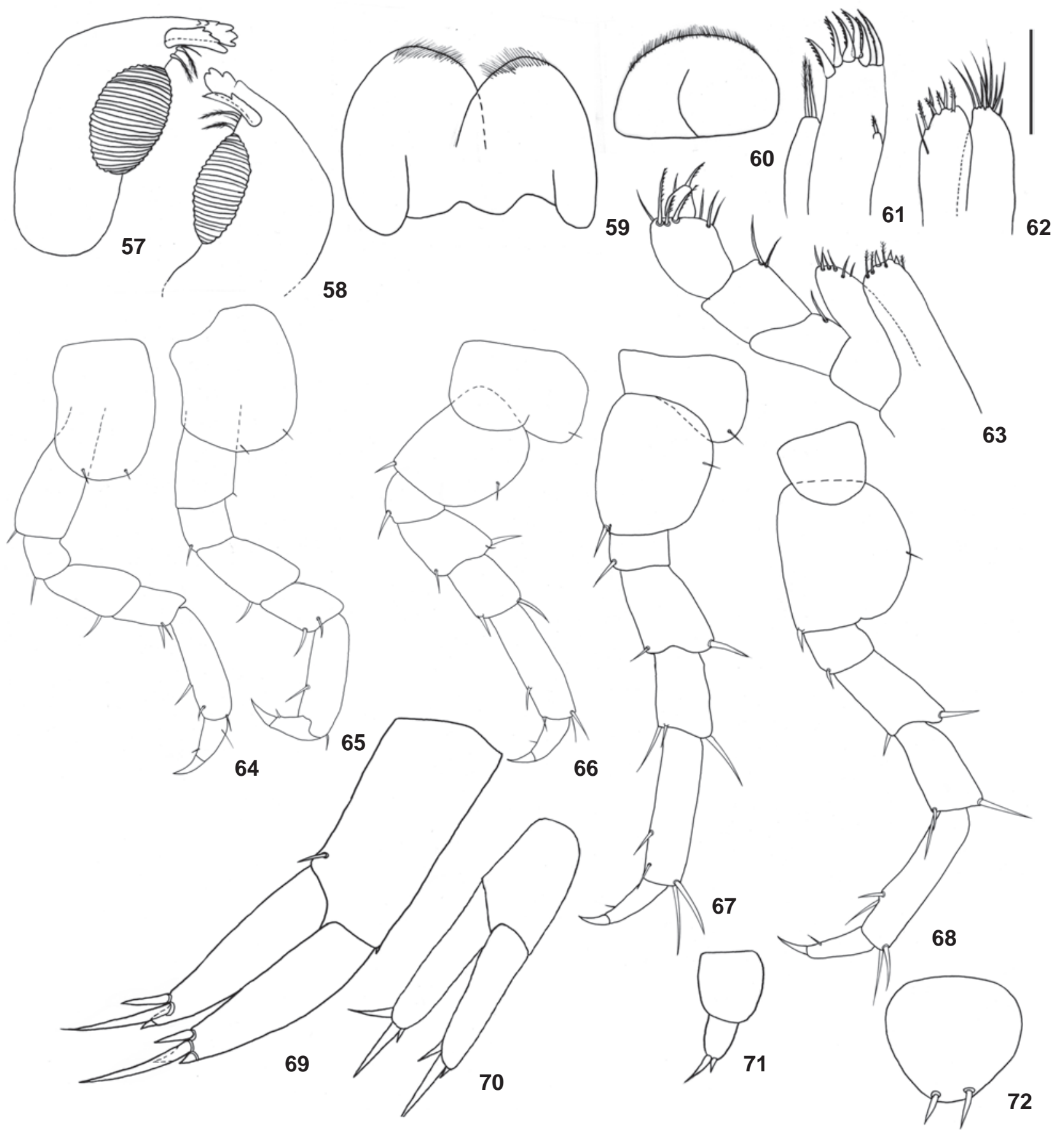

Figures 57-72. Hyalella pleoacuta, appendages in the first post-marsupial developmental stage: (57-63) left and right mandibles, lower and upper labia, maxillae 1 and 2 and maxilliped, respectively (scale $0.05 \mathrm{~mm}$ ); (64-68) pereopods 3, 4, 5, 6 and 7, respectively (scale $0.1 \mathrm{~mm}$ ); (69-72) uropods 1,2 and 3 and telson, respectively (scale $0.05 \mathrm{~mm}$ ).

Maxilla 2 (Fig. 77): similar in shape to that of S-1, but inner plate, in addition to the A2 (Fig. 2), D5 (Fig. 16) and E1 setae (Fig. 18), bears F1 serrate setae.
Maxilliped (Fig. 79): shaped similarly to that of the S-1 juvenile, but with greater density of setae, and article 2 of the palp with A2 simple setae (Fig. 2). 


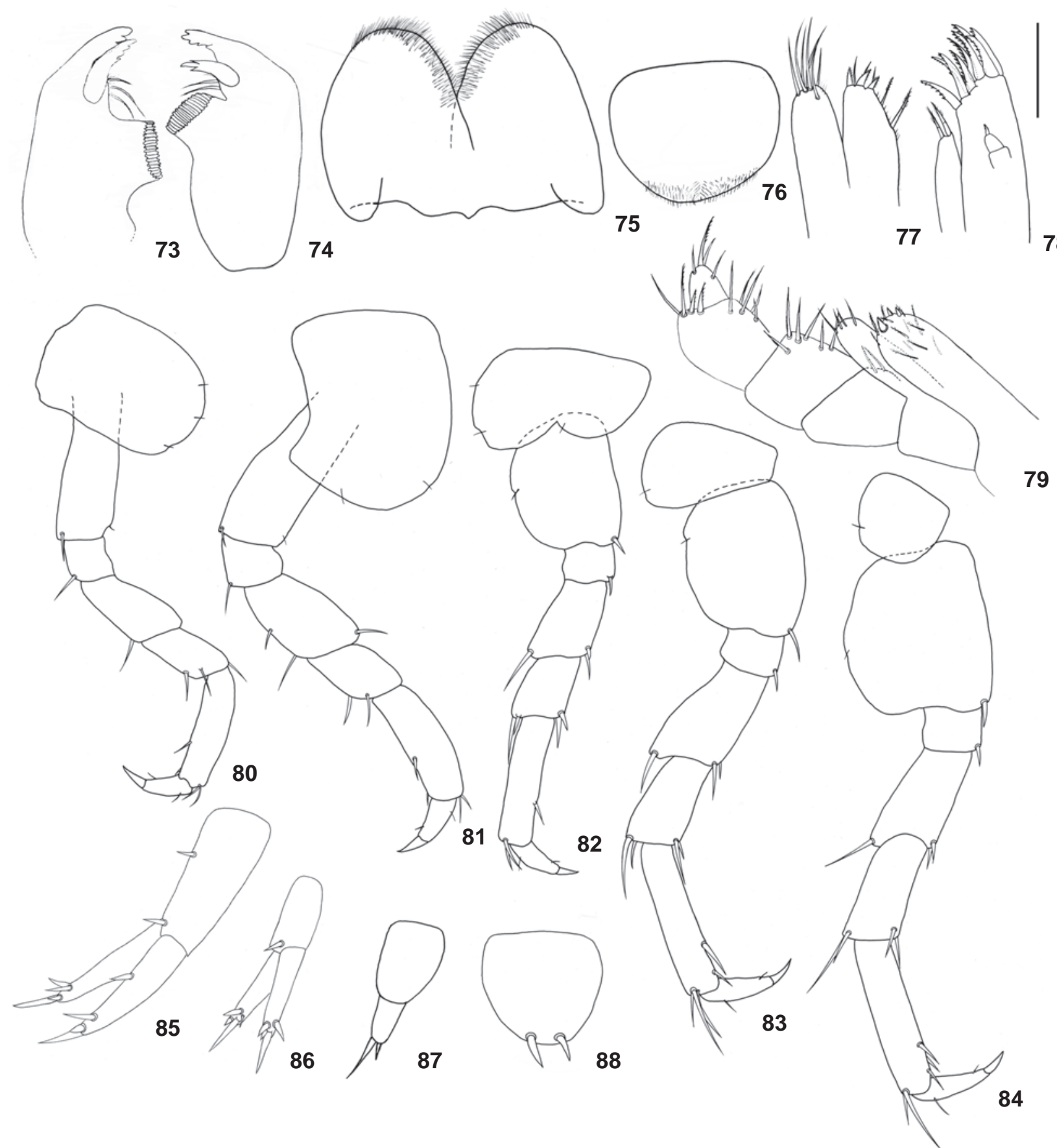

Figures 73-88. Hyalella pleoacuta, appendages in the third post-marsupial developmental stage: (73-79) left and right mandibles, lower and upper labia, maxillae 1 and 2 and maxilliped, respectively (scale $0.05 \mathrm{~mm}$ ); (80-84) pereopods 3, 4, 5, 6 and 7, respectively (scale $0.1 \mathrm{~mm})$; (85-88) uropods 1,2 and 3 and telson, respectively (scale $0.05 \mathrm{~mm}$ ).

Pereopods (Figs 80-84): Similar to S-1 in shape and type of setae, but with more setae. Differs from previous stage in the coxa of pereopod 7, which in S-1 has no setae and in this stage has 1 A10 simple seta (Fig. 8).
Uropod 1 (Fig. 85): total length approximately $1 / 4$ that of the pereopods. Rami with the same types of setae as in S-1, with subapical B6 setae (Fig. 13), and B2 (Fig. 11) with the region above the annulation differentiated from the rest of the 
seta (Fig. 11 shows this seta in S-4, which has the same appearance as in S-3).

Uropod 2 (Fig. 86): its length approximately half that of uropod 1. Same types of setae as in S-1, with the subapical B6 (Fig. 13) setae and the B2 seta (Fig. 11) with the same appearance as in uropod 1.

Uropod 3 (Fig. 87): its total length approximately $2 / 3$ length of uropod 2. Same types of setae as in S-1.

Telson (Fig. 88): almost same size as in S-3. Same types of setae as in S-1.

Pereonite 7 and pleonites 1, 2 and 3 with flanges, as in the adult.

\section{Mouthparts, pereopods, uropods and telson in stage 4}

The mouthparts, pereopods, uropods and telson of stage 4 are similar to those of stage 3 , except in the number of setae on each article of these appendages (Tab. I).

\section{DISCUSSION}

\section{Cuticular structures}

Thirty kinds of cuticular structures were found: simple setae (seven), cuspidate setae (five), plumose setae (two), pappose setae (four), serrulate setae (one), serrate setae (four), setule (one), denticles (two), pores (two), and penicillia. All these are found in the adults of $H$. pleoacuta and $H$. castroi (Zimmer et al. 2009). Not all the structures present in the adults were found in the juveniles: $\mathrm{S} 1$ setules, and A6, A7, A9, B4, D1, D2 and E2 setae, indicating that the different types of setae arise in the course of the molts, such as, for example, the A9 seta and S1 setule that occur on the oostegites of the adult females, and the B4 seta, a curved seta characteristic of the inner ramus of uropod 1 of the males of some species of Hyalella, including $H$. pleoacuta (GonzÁlez et al. 2006, Zimmer et al. 2009). These types of setae were not found until S-4, indicating that sexual differentiation does not occur until this stage.

\section{Modifications of the Setae}

There was a general tendency in all the appendages for an increase in the number of setae and in the setules on the plumose, pappose, serrulate and serrate setae, and an increase in the shaft of practically all the setules and setae in the different stages. This can be observed in figures 24 and 25, which show the $\mathrm{S} 2$ setules on the upper labium of S- 1 and S- 4 respectively; the setules of the $S-1$ have much smaller shafts than those of the S-4.

The B2 cuspidate seta present on the rami of uropod 1 underwent extensive morphological changes in the different stages. In S-1 (Fig. 10) the region near the base is not differentiated, with a constant diameter up to the annulation. In S-4 (Fig. 11) the initial part is narrower, and widens before the annulation. The length of the setules on the setae also increases with the stage, as in figures 20 and 21, which show the F3 serrate seta on the carpus of the gnathopod in S-1 and S- 4 respectively. Together with the increase in length of the setules, there was a proportional decrease in the size of the apex.

The polygonal pattern is seen in several appendages, as well as on the body surface. Its formation occurs in the course of the stages, with an increase in the number of denticles as well as in the size of those already existing (Figs 27 and 28). In the later stages (unpublished data), this pattern becomes more evident. The carpus and propodus in S-1 have denticles, but it is not possible to differentiate them in $\mathrm{T} 1$ and $\mathrm{T} 2$, only from S2 on. In S-2 it is possible to observe the pectinate border of the carpus (Fig. 30), in a similar configuration to that of the adult (GonZalez et al. 2006).

Although there is a clear change in the format of the cuticular structures, no change in the type of seta was observed. Cate \& Derby (2002) showed that the morphology of "wooded sensilla", present on the telson of the spiny lobster, can undergo distinct changes after a single molt. Their observations showed the apparent change of the plumose seta on the exuvium to the "wooded sensilla" on the new carapace of a small percentage of the specimens examined. The authors observed, however, that most of the setae did not change in their morphology after a single molt. KAÏM-MALKA (2004) described the development of the oostegites of the amphipod Tmetonyx similis (G.O. Sars, 1891) during sexual maturation, and also observed modifications in the shape of the setae. They arise in a certain stage and continue to change form with successive molts, becoming larger and wider with time.

Schmiтz (1992) and Schmitz et al. (1993), studying the postembryonic development of the crayfish Procambarus clarkii Girard, 1852, observed that the "plumage" of the plumose seta on the telson increased after successive molts. Noro et al. (2005) observed differences in the setae of the juveniles and the adult of Parastacus brasiliensis (von Martens, 1869), such as the teasel seta in the juvenile, with the denticles more elongated and separated than in the adults. Other investigators have recorded an increase in the number of setae with development of juveniles in decapods (Bueno \& Bond-Buckup 1996, Sandeman \& Sandeman 1996, Stuart \& Macmillan 1997, Harrisson et al. 2001).

\section{Morphology of the appendages of S-1 to S-4}

The number of articles of the flagellum of both antennae is constant in S-1 and S-2, and afterwards begins to change. The right and left antennae of the same individual may vary, as also observed by Leite (1996) for A. neapolitanus and $A$. ramondi. There was a tendency to increase one article in each stage, except for antenna 1 in Stage 3. This tendency was also observed by LeITe (1996) and LeITE \& GÜTH (2003).

There was a tendency for the increase of the coxal plate in relation to the propodus in both gnathopods. The propodus of gnathopod 2 increased in size until stage 4 , showing that there was no sexual differentiation until this stage, as also observed by CASTIGLIONI et al. (2007).

The upper and lower labia in S-1, S-4 and the adult showed a width/height ratio greater than 1 . However this ratio is larger in S-1 than in S-4, and is larger in S-4 than in the adult. Maxilla 
1 of the adults always has nine serrate setae on the outer plate (GonZÁlez et al. 2006, Zimmer et al. 2009), and this number increases with progressive stages until S-4.

The uropods undergo considerable change in proportion in relation to the body, becoming proportionally smaller as the stages progress. The curved seta that is typical of males of this species was not observed in any stage. The telson, an important structure in species identification (GonzÁlez \& WATLING 2001, GonZÁLEZ et al. 2006), shows a constant number and type of setae; however with development its form is modified, since in juveniles in S-3 and S-4 it is wider than long, whereas in the adult the length and width are similar. There was a tendency toward a decrease in the proportion of width to length of this appendage.

As noted above, there is a good deal of overlap of characteristics in two consecutive stages, including of the number of articles of the antennas, which is often used to separate the developmental stages. It is quite difficult, therefore, to identify the stages only by the characteristics presented here. Early identification of the species (in stage 1 ) is possible due to the presence of the flanges on pereonite 7 and pleonites 1-3. The other diagnostic characteristics of the species, however, appear during the course of development and ought not to be used for taxonomic identification.

\section{ACKNOWLEDGMENTS}

We thank CNPq for a Master's fellowship to DLGS and for a scientific productivity grant to PBA.

\section{LITERATURE CITED}

Aikins, S. \& E. KikUCHI. 2001. Studies on habitat selection by amphipods using artificial substrates within an estuarine environment. Hydrobiologia 457: 77-86.

Bellan-Santini, D. 1999. Ordre des amphipodes(Amphipoda Latreile, 1816). 19: 93-176. In: A. J. Forest (Ed.). Traité de zoologie. Anatomie, systématique, biologie (Pierre-P. Grasse). Tome VII, Fascicule IIIA, Crustacés Péracarides Memoires de'l Institut Oceanographique, Fondation Albert Ier, Prince de Mônaco, 450p.

Bueno, A.A.P. \& G. Bond-Buckup. 1996. Os estágios juvenis iniciais de Aegla violacea Bond-Buckup \& Buckup (Crustacea, Anomura, Aeglidae). Nauplius 4: 39-47.

Cate, H.S. \& C.D. Derby. 2002. Hooded sensilla homologues: structural variations of a widely distributed bimodal chemomechanosensillum. The Journal of Comparative Neurology 444: 345-357.

Castiglioni, D.S. \& G. Bond-Buckup. 2007. Reproductive strategies of two sympatric species of Hyalella Smith, 1874 (Amphipoda, Dogielinotidae) in laboratory conditions. Journal of Natural History 41 (25-28): 1571-1584.

Castiglioni, D.S.; D.L. Garcia-Schroeder; D.F. Barcelos \& G. BondBuckup. 2007 Intermolt duration and postembryonic growth of two sympatric species of Hyalella (Amphipoda, Dogielinotidae) in laboratory conditions. Nauplius 15 (1): 57-64.

González, E.R.; G. Bond-Buckup \& P.B. Araujo. 2006. Two new species of Hyalella from southern Brazil (Amphipoda: Hyalellidae) with a taxonomic key. Journal of Crustacean Biology 26 (3): 355-365.

GonzÁlez, E.R. \& L. WatLing. 2001. Three new species of Hyalella from Chile (Crustacea: Amphipoda: Hyalellidae). Hydrobiologia 464: 175-199.

Harrison, P.J. H.; S.E. Cate; H.S. Swanson \& C.D. Derby. 2001. Postembryonic proliferation in the spiny lobster antennular epithelium: rate of genesis of olfactory receptor neurons is dependent on molt stage. Journal of Neurobiology 47: 5166.

KaÏm-MaLKA, R.A. 2004. Oostegite development during the sexual maturation of females of Tmetonyx similis (G.O. Sars, 1891) (Amphipoda, Lysianassidae). Journal of Natural History 38: 2403-2424.

Leistikow, A. \& P.B. Araujo. 2001. Morphology of respiratory organs in South American Oniscidea (Philosciidae), p. 329336. In: B. Kensley \& R. BRusca (Eds). Isopod Systematics and Evolution, Rotterdam, A.A. Balkema, Crustacean Issues 13 , VIII+357p.

LeITE, F.P.P. \& A.Z. GÜTH. 2003. Variações morfológicas dos estágios pós- marsupiais de Sunampithoe pelagica Milne-Edwards (Crustacea, Amphipoda, Gammaridea, Ampithoidae) da fauna de Sargassum cymosum C. Agaerh. Revista Brasileira de Zoologia 20 (1): 65-73.

Leite, F.P.P. \& P.E.P. Leite. 1997. Desenvolvimento morfológico e dos ovários de Kalliapseudes schubarti Mañe-Garzon (Crustacea, Tanaidacea) do canal de São Sebastião, São Paulo, Brasil. Revista Brasileira de Zoologia 14 (3): 675-683.

Leite, F.P.P. \& Y. WAKABARA. 1989. Aspects of marsupial and postmarsupial development of Hyale media (Dana) 1853 (Hyalidae, Amphipoda). Bulletin of Marine Science 45 (1): 85-87.

LeITE, F.P.P.1996. Alterações morfológicas dos estágios de crescimento de Amphilocus neapolitanus Della Valle, 1983 (Gammaridea, Amphipoidea) e Ampithoe ramondi Audouin, 1826 (Gammaridea, Amphipoidea) anfípodos associados à alga Sargassum cymosum. Revista Brasileira de Zoologia 13: 47-60.

Morino, H. 1978. Studies on the Talitridae (Amphipoda, Crustacea) in Japan. III. Life history and breeding activity of Orchestia platensis Kroyer. Publications of the Seto Marine Biological Laboratory 24 (4-6): 245-267.

Neuparth, T.; F.O. Costa \& M.H. Costa. 2002. Effects of temperature and salinity on life history of the marine amphipod Gammarus locusta. Implications for ecotoxicological testing. Ecotoxicology 11: 55-67.

Muskó, I.B. 1993. The life history of Corophium curvispinum G.O. Sars (Crustacea, Amphipoda) living on macrophytes in Lake Balaton. Hydrobiologia 480: 243-244. 
Noro, C.K.; L. Buckup \& G. Bond-Buckup. 2005. The juvenile stages of Parastacus brasiliensis (von Martens, 1869) (Crustacea, Decapoda, Parastacidae). Journal of Natural History 39 (21): 1851-1873.

PAGE, H.M. 1979. Relationship between growth, size, molting and number of antennal segments in Orchestia traskiana Stimpson (Amphipoda Talitridae). Crustaceana 37 (3): 247252.

Pilgrim, w. \& M.D. Burt. 1993. Effect of acute pH depression on the survival of the freshwater amphipod Hyalella azteca at variable temperatures: field and laboratory studies. Hydrobiologia 254: 91-98.

Rinderhagen, M.; J. Ritterhoff \& G. Zauke. 2000. Crustaceans as Bioindicators. Biomonitoring of Polluted Water - Reviews on Actual Topics (A. Geerhardt, ed.), Trans Tech Publications, Environmental Research Forum 9: 161-194.

RYGG, B. 1974. Identification of juvenile Baltic gammarids (Crustacea, Amphipoda). Annales Zoologici Fennici 11 (3): 216-219.

Sandeman, R.E. \& D.C. Sandeman. 1996. Pre- and postembryonic development, growth and turnover of olfactory receptor neurons in crayfish antennules. Journal of Experimental Biology 199: 2409-2418.

Schmitz, B. 1992. Postembryonic development of the crayfish Procambarus clarkii and its tailfan mechanosensory system, p. 69-90. In: R.N. SINGH (Ed.). Nervous systems: principles of design and function. New Delhi, Wiley Eastern, 506p.
Schmitz, B.;W. Bosch \& R. Drömer. 1993. The telson mechanosensory system in the crayfish Procambarus clarkii: development and connectivity in the central nervous system, p. 431-438. In: K. Wiese; F.G. Gribakin; A.V. Popov \& G. Renninger (Eds). Sensory systems of arthropods. Basel, Birkhäuser Verlag, 696p.

SeXton, E.W. \& D.M. Reid. 1951. The life history of the multiform species Jassa falcata (Montagu) (Crustacea, Amphipoda) with review of the bibliography of the species. Journal of the Linnean Society 42 (283): 28-88.

Sтоск, J.H. 1987. Stygofauna of Canary Island, 5. A Hypogean population of Parhyale (Amphipoda) in the Jameos del Agua lava tunnel (Lanzarote) a supposed case of recent evolution. Stygologia 3: 167-184.

Stuart, T. \& D. Macmillan. 1997. Development of spines and sensory setae on the tailfan of the Southern rock lobster (Jasus edwardsii Hutton, 1875; Crustacea: Decapoda). Australian Journal of Zoology 45: 307-315.

Ungerer, P. \& C. WolfF. 2005. External morphology of limb development in the amphipod Orchestia cavimana (Crustacea, Malacostraca, Peracarida). Zoomorphology (124): 89-99.

Wellborn, G.A. 1995. Determinants of reproductive success in freshwater amphipod species that experience different mortality regimes. Animal Behavior 50: 353-363.

Zimmer, A.; P.B. Araujo \& G. Bond-Buckup. 2009. Diversity and arrangement of the cuticular structures of Hyalella (Crustacea, Amphipoda, Dogielinotidae) and their use in taxonomy. Zoologia 26 (1): 127-142.

Submitted: 15.VII.2008; Accepted: 01.IX.2009.

Editorial responsibility: Marcos Domingos Siqueira Tavares 